\title{
Bahasa Inggris untuk Fakultas Dakwah \& Ilmu Komunikasi (Tinjauan Umum Berdasarkan KKNI)
}

\author{
Arwemi ${ }^{1}$ \\ 1 UIN Imam Bonjol Padang \\ Email : arwemi@gmail.com
}

\begin{abstract}
ABSTRAK
Matakuliah Bahasa Inggris untuk Fakultas Dakwah merupakan matakuliah MKDU atau matakuliah umum yang bukan matakuliah major (non-major English). Bagaimana sosok, dan kompetensi apa yang akan diberikan kepada mahasiswa fakultas ini? Artikel ini mencoba mengeksplorasi kebutuhan bahasa Inggris untuk FDIK secara umum, dan selintas untuk setiap prodi di FDIK. Terdapat beberapa variasi kebutuhan lulusan setiap prodi terhadap bahasa Inggris. Prodi KPI dan MD lebih kepada kompetensi speaking, BKI untuk reading comprehension, prodi PMI memerlukan keduanya, terutama untuk interaksi dengan referensi dan lembaga internasional
\end{abstract}

Keyword : FDIK, Bahasa Inggris, outcomes, KKNI

\section{ABSTRACT}

English courses for Dakwah Faculty are MKDU (General and Basic Courses) courses or general courses that are not major subjects (non-major English). What figures and competencies will be given to students of this faculty? This article tries to explore the needs of English for FDIK (Dakwah and Communication Science Faculty) in general, and at a glance for each department in FDIK. There are several variations in the needs of graduates of each department on English. KPI (Islamic Broadcasting Communication) and MD (Dakwah Management) departments are more in speaking competence, BKI (Islamic Counseling) for reading comprehension, PMI (Islamic Social Development) department needs both, especially for interactions with international references and institutions Key words: Dakwah Faculty, English, outcomes, KKNI

\section{PENDAHULUAN}

Fakultas Dakwah \& Ilmu Komunikasi, FDIK, adalah bagian dari PTKIN di dalam lingkungan Kementerian Agama RI dan bagian integral dari pendidikan tinggi
Indonesia secara keseluruhan. Berdasarkan Peraturan Presiden Republik Indonesia Nomor 8 Tahun 2012 tentang Kerangka Kualifikasi Nasional Indonesia (KKNI), FDIK dituntut melakukan penyesuaian segala lini, termasuk dalam 
penyusunan kurikulum dan silabus pembelajaran Bahasa Inggris.

Peraturan Menteri Riset, Teknologi dan Pendidikan Tinggi Republik Indonesia Nomor 44 Tahun 2015 tentang Standar Nasional Pendidikan Tinggi sebagai kelanjutan dari peraturan pemerintah tentang KKNI, serta turunannya, Peraturan Menteri Agama Nomor 1 Tahun 2016 tentang Ijazah, Transkip

Akademik, dan Surat Keterangan Pendamping Ijazah Perguruan Tinggi Keagamaan merupakan satu kesatuan dalam rangka pencapaian Standar Nasional Pendidikan Tinggi (SN-Dikti).

Sebagai implementasi dari segenap peraturan tersebut, Direktorat Pendidikan Tinggi Keagamaan Islam Direktorat Jendral Jendral Pendidikan Islam telah mengeluarkan Panduan Pengembangan Kurikulum PTKI Mengacu pada KKNI dan SN-Dikti pada bulan Mei tahun 2018.

Secara gradual telah tersusun auran yang cukup lengkap bagi FDIK untuk menindaklanjuti pada tataran fakultas. Perlu kiranya para pemangku kebijakan tingkat PTKI umumnya, dan tingkat FDIK khususnya untuk melakukan melakukan usaha penyelarasan, terutama melakukan pembaharuan kurikulum dan silabus semua mata kuliah. Termasuk dalam hal ini mata kuliah Bahasa Inggris. Kemampuan apa yang diharapkan pada proses pembelajaran.

Berdasarkan KKNI, rumusan kemampuan diberi istilah "capaian pembelajaran" (learning outcomes). Kemampuan mencakup atau merupakan bagian dari capaian pembelajaran (CP). Penggunaan istilah kompetensi dalam pendidikan tinggi selama ini setara dengan capaian pembelajaran yang digunakan dalam
KKNI. Tetapi, di dunia kerja penggunaan istilah kompetensi diartikan sebagai kemampuan yang sifatnya lebih terbatas, terutama yang terkait dengan uji kompetensi dan sertifikat kompetensi. maka dalam kurikulum KKNI pernyataan "kemampuan lulusan" digunakan istilah capaian pembelajaran. Di dalam kerangka kualifikasi di dunia internasional, deskripsi kemampuan setiap jenjang kualifikasi digunakan istilah "learning outcomes".

KKNI adalah kerangka untuk mewujudkan mutu dan jati diri bangsa Indonesia melalui sistem pendidikan nasional, sistem pelatihan kerja nasional, dan sistem penilaian kesetaraan capaian pembelajaran nasional, untuk menghasilkan sumber daya manusia nasional yang bermutu dan produktif.

\section{CP Bahasa Inggris untuk FDIK, Bagaimana Sosoknya?}

Bahasa Inggris di PTKI, khususnya FDIK, sebagaimana di perguruan tinggi umum lainnya yang bukan merupakan prodi Bahasa Inggris (non-English Majors), biasanya dimasukkan ke dalam kategori Matakuliah Pengembangan Kepribadian (MPK), atau dalam kurikulum sebelumnya disebut dengan Mata Kuliah Dasar Umum (MKDU). Menurut Kepmendiknas Nomor: 232/U/2000, mata kuliah ini termasuk kurikulum institusional, dimana isi dan orientasinya ditentukan oleh masing-masing institusi menurut ciri khas perguruan tinggi yang bersangkutan. Disini terlihat peluang bagi masing-masing fakultas dan prodi melakukan penyusunan dan pengembangan secara mandiri.

Kurikulum tersebut nantinya dapat di breakdown sesuai dengan prodi yang ada 
di UIN. Selain pengembangan keilmuan, kurikulum ini juga berkaitan dengan nilai dalam setiap mata kuliah. Setiap mata kuliah nantinya akan ada konsorsium keilmuan di bawah koordinasi Kementerian Agama untuk melihat perkembangan dan evaluasi kurikulum berbasis KKNI tersebut.

FDIK bukanlah fakultas yang mempelajari Bahasa Inggris sebagai mata kuliah major (non-major English). Karena itu outcomes pembelajaran Bahasa Inggris lebih ditentukan oleh kompetensi utama lulusan setiap prodi yang ada di FDIK.

Secara umum, seluruh prodi FDIK berinteraksi dengan referensi berbahasa Inggris, tanpa kecuali. Prodi Komunikasi Penyiaran Islam, Prodi Konseling Islam, Prodi Manajemen Dakwah, dan Prodi Pengembangan Masyarakat Islam, semuanya terkait dengan ilmu pengetahuan yang berkembang di dunia secara luas. Ilmu Komunikasi, Ilmu Konseling, Ilmu Manajemen, dan Ilmu Pengembangan Masyarakat adalah ilmuilmu yang sedang berkembang pesat di seluruh dunia. Demikian juga referensi, jurnal-jurnal, dan buku-buku rujukan, semua berkembang, terutama dalam Bahasa Inggris.

Maka dapat diambil sebuah kesimpulan utama, untuk seluruh prodi di FDIK harus mempunyai kompetensi membaca teksteks keilmuan yang sedang berkembang pesat, terutama jurnal-jurnal keilmuan internasional. Kompetensi membaca teks, Reading Comprehension, adalah outcomes yang mau tidak mau, suka tidak suka, harus dikuasai oleh seluruh mahasiswa FDIK tanpa kecuali.

Secara spesifik, setiap prodi mempunyai kekhususan dalam profesi yang akan mereka arungi di masyarakat nantinya.
Kompetensi Bahasa Inggris seorang sarjana Komunikasi Penyiaran Islam yang akan berinteraksi dengan media massa, apalagi harus tampil sebagai seorang presenter atau penyiar di radio dan televisi, tentulah menuntut kemampuan speaking, kemampuan berbicara bahasa Inggris yang rapih dan tidak mengandung kesalahan-kesalahan elementer berbahasa, seperti pronounciation, spelling, dan semacamnya. Maka dalam hal ini, prodi KPI perlu fokus memperkuat mahasiswa dengan kemampuan speaking yang dapat diandalkan. Walaupun bukan presenter atau penyiar Bahasa Inggris, setip kosa kata serapan dari Bahasa Inggris harus diucapkan secara rapih, kalau tidak ingin menjadi bahan tertawaan audien, baik pendengar radio, maupun pemirsa televisi.

Tuntutan tersebut menjadikan Bahasa Inggris untuk prodi KPI di FDIK harus lebih mengkhususkan kompetensi speaking bagi mahasiswanya. Kebutuhan tersebut mungkin lebih banyak daripada kebutuhan membaca teks referensi, reading comprehension. Setidaknya, jika dibuat prosentase untuk empat ketrampilan utama berbahasa Inggris mahasiswa KPI yang akan menjadi fokus silabus Bahasa Inggris, adalah sebagai berikut;

$\begin{array}{ll}\text { speaking (berbicara) } & >35 \%\end{array}$

listening (mendengar) > $35 \%$

reading (membaca) $>20 \%$

writing (menulis) > $10 \%$

Kompetensi Bahasa Inggris seorang sarjana Konseling Islam yang akan berinteraksi dengan klien yang berbahasa Indonesia, tidaklah menuntut kemampuan speaking dan listening, tidak dituntut kemampuan berbicara bahasa 
Inggris yang rapih yang memerlukan pronounciation, spelling, dan semacamnya. Maka dalam hal ini, prodi BKI tidak perlu fokus memperkuat mahasiswa dengan kemampuan speaking. Bahasa Inggris untuk prodi BKI di FDIK harus lebih mengkhususkan kompetensi readingbagi mahasiswanya. Kebutuhan lebih banyak terhadap kebutuhan membaca teks referensi, reading comprehension. Bidang keilmuan Konseling yang lebih banyak perkembangannya di dunia berbahasa Inggris, tentu perlu dijelajahi oleh calon konselor secara baik. Setidaknya, jika dibuat prosentase untuk empat ketrampilan utama berbahasa Inggris mahasiswa BKI yang akan menjadi fokus silabus Bahasa Inggris, adalah sebagai berikut;

speaking (berbicara) $\quad>15 \%$
listening (mendengar) $>15 \%$
reading (membaca) $>50 \%$
writing (menulis) > $20 \%$

Kompetensi Bahasa Inggris seorang sarjana Manajemen Dakwah, tidaklah menuntut kemampuan speaking dan listening, yang terlalu fasih. Tapi karena tetap akan berinteraksi dalam sistem manajemen yang melibatkan organisasi dan kalangan manajerial, Bahasa Inggris yang rapih diperlukan juga di prodi ini. Prodi MD tidak perlu fokus memperkuat mahasiswa dengan kemampuan tertentu, karena semua ketrampilan berbahasa Inggris bagi seorang calon manajer diperlukan.

Bahasa Inggris untuk prodi MD di FDIK tidan harus lebih mengkhususkan kompetensi tertentu bagi mahasiswanya. Semua ketrampilan Bahasa Inggris secara mendasar perlu dikuasai oleh seorang calon manajer, calon sarjana Manajemen
Dakwah. Jika dibuat prosentase untuk empat ketrampilan utama berbahasa Inggris mahasiswa MD yang akan menjadi fokus silabus Bahasa Inggris, adalah sebagai berikut;

speaking (berbicara) > $\quad>25 \%$

listening (mendengar) $>25 \%$

reading (membaca) $>25 \%$

writing (menulis) $>25 \%$

Kompetensi Bahasa Inggris seorang sarjana Konseling Islam yang akan berinteraksi dengan klien yang berbahasa Indonesia, tidaklah menuntut kemampuan speaking dan listening, tidak dituntut kemampuan berbicara bahasa Inggris yang rapih yang memerlukan pronounciation, spelling, dan semacamnya. Maka dalam hal ini, prodi BKI tidak perlu fokus memperkuat mahasiswa dengan kemampuan speaking. Bahasa Inggris untuk prodi PMI di FDIK harus lebih mengkhususkan kompetensi reading bagi mahasiswanya. Kebutuhan lebih banyak terhadap kebutuhan membaca teks referensi, reading comprehension. Bidang keilmuan Pengembangan Masyarakat, Komunikasi Innovasi, Komunikasi Pembangunan, yang lebih banyak perkembangannya di dunia berbahasa Inggris, tentu perlu dijelajahi oleh calon sarjana PMI secara baik. Di samping itu, kompetensi calon sarjana pengembangan Masyarakat dituntut dapat melahirkan tulisan- dan laporan yang bermutu, kalau dapat menjadi isi jurnal internasional berbahasa Inggris. Jika dibuat prosentase untuk empat ketrampilan utama berbahasa Inggris mahasiswa PMI yang akan menjadi fokus silabus Bahasa Inggris, adalah sebagai berikut; speaking (berbicara) > $\quad>15 \%$ listening (mendengar) $\quad>15 \%$ 
reading (membaca) $>40 \%$

writing (menulis) $>30 \%$

Jika keempat prodi di FDIK tersebut menyusun silabus dan rencana pembelajaran Bahasa Inggri, maka perlu dipertimbangkan penyusunan secara mandiri masing-masing prodi. Tidaklah tepat silabus untuk prodi yang satu dipakai begitu saja untuk prodi lainnya. Terdapat kebutuhan-kebutuhan khusus pada setiap prodi. Adalah lucu, misalnya, seorang sarjana Konseling terlalu mendalam mempelajari speaking, pronounciation, spelling dan semacamnya, padahal semua itu tidak akan terpakai dalam dunia profesinya sebagai konselor masyarakat kelak.

Juga menjadi lucu, jika seorang lulusan KPI yang diuji sebagai calon penyiar di radio atau televisi tidak mampu mengucapkan secara rapih ungkapanungkapan Bahasa Inggris sehari-hari (daily English).

Ringkasan uraian di atas adalah, perlu adanya penyusunan silabus dan bahan ajar yang berbeda untuk setiap prodi di FDIK. Kekhususan masing-masing prodi, dan kompetensi, serta outcomes yang diharapkan dalulusan masing-masing harus spesifik danlam rangka mencapai Kerangka Kualifikasi Nasional Indonesia, KKNI.

\section{KESIMPULAN}

Dalam menyusun kerangka
kurikulum KKNI fakultas dakwah
diperlukan pengkajian yang mendalam,
diantaranya adanya aspek kompetensi
masing-masing bidang dan hasil
lulusannya.
Daily english perlu dilatih untuk
masa-masa yang akan datang

menghadapi tantangan zaman yang semakin berkembang dan cepat.

Juru dakwah harus cepat dan tanggap menghadapi perobahan yang terjadi dimasa yang akan datang maka perlu suatu penelitian dan telaah lebih mendalam

Harapan kedepannya para akademisi lebih fokus lagi melihat perobahan dan kemajuan teknologi dibarengi dengan pembekalan yang cukup bagai generasi muda kita

\section{DAFTAR KEPUSTAKAAN}

Peraturan Presiden Republik Indonesia Nomor 8 Tahun 2012 tentang Kerangka Kualifikasi Nasional Indonesia (KKNI)

Peraturan Menteri Riset, Teknologi dan Pendidikan Tinggi Republik Indonesia Nomor 44 Tahun 2015 tentang Standar Nasional Pendidikan Tinggi

Peraturan Menteri Agama Nomor 1 Tahun 2016 tentang Ijazah, Transkip

Akademik, dan Surat Keterangan Pendamping Ijazah Perguruan Tinggi Keagamaan

Panduan Pengembangan Kurikulum PTKI Mengacu pada KKNI dan SN-Dikti pada bulan Mei tahun 2018.

Menurut Kepmendiknas Nomor: 232/U/2000

Tentang

Peengembangan Kurikulum Pendidikan Tinggi 